http://nv.nltu.edu.ua

https://doi.org/10.15421/40280515

Article received 18.05.2018 $p$.

Article accepted 31.05.2018 p.
$@ \bowtie$ Correspondence author

I. Ye. Kulchytskyi-Zhyhaylo ikylchytski@ukr.net

I. Є. Кульчицький-Жигайло

Національний лісотехнічний університет України, м. Львів, Украйна

\title{
ХАРАКТЕР РОЗТАШУВАННЯ ЛІСІВ НА ВОДОЗБОРІ ГІРСЬКОЇ РІЧКИ В КАРПАТАХ ЯК ОДИН 3 ЧИННИКІВ ФОРМУВАННЯ ВИТРАТ ВОДИ ВЕСНЯНОГО ВОДОПІЛЛЯ
}

\begin{abstract}
Оцінено можливість застосування показника розвитку лісистості водозбирання $\varepsilon$ для характеристики розташування лісів на ньому. Встановлено малу інформативність $\varepsilon$ для лісогідрологічних досліджень. Проаналізовано опубліковані експериментальні дослідження та матеріали Закарпатської воднобалансової станції про вплив хвойних і листяних лісів на величину снігонакопичення та інтенсивність сніготанення в Карпатах. Вивчено морфометричні характеристики досліджуваного водозбору річки Яблунька до м. Турка в Бескидах, розташування лісів на ньому, їх породний і віковий склад. Площа водозбо-

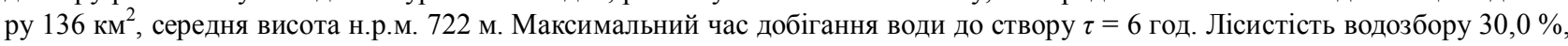
$95 \%$ площі займають деревостани з переважанням ялини європейської та ялиці білої. При різному розташуванні лісів на цьому водозборі змодельовано погодинну витрату води на підйомі гідрографу для типового температурного режиму в період весняного сніготанення. Встановлено, що для малих водозборів, де $\tau$ у десятки разів менший від часу сніготанення, характер розташування лісів не відіграє значної ролі у формуванні середньогодинних витрат води. Різниця між витратами води весняного водопілля для різних варіантів розташування лісів, спричинена відтермінуванням початку сніготанення у хвойних лісах, не перевищує $10 \%$. За синхронної зміни інтенсивності сніготанення в лісі та на відкритих ділянках різниця між витратами води для різного розташування лісів становить 1-3 \%; за асинхронної зміни - 3-7 \%.
\end{abstract}

Ключові слова: гідрологічний вплив хвойних лісів; показник розвитку лісистості; снігові води; моделювання гідрографа стоку.

Вступ. Величина прояву гідрологічних функцій лісів певною мірою залежить від характеру їх розташування на водозборі (Podkur, 1981). Стокорегулювальний вплив лісів на формування стоку в багатоводні фази водного режиму оцінюють укрупнено для двох випадків: ліси зосереджені у верхній чи нижній частині басейну (Dubakh, 1951). Розташування у верхній частині вважають кращим для зменшення максимального стоку весняних водопіль на підставі таких міркувань: позаяк лісові екосистеми відтерміновують початок сніготанення та зменшують його інтенсивність (збільшуючи тривалість) (Broxton, et al., 2015; Mahat, \& Tarboton, 2014), талі води 3 нижньої безлісної частини басейну встигають стекти ще перед тим, як надійде друга хвиля. I навпаки, якщо ліси, що розташовані у нижній частині водозбору, відтермінують і сповільнять сніготанення, хвиля 3 верхньої частини водозбору дожене хвилю 3 нижньої і накладеться на неї, збільшуючи максимальну витрату води (Kantor, 1981; Oliinyk, 2013).

Запропоновано показник розвитку лісистості водозбору $\varepsilon$ (Pociask-Karteczka, 2003), гідрологічна оцінка величини якого також базується на наведеному вище підході. Його розраховують за формулою: $\varepsilon=F_{1} / F_{2}$, де $F_{1}$ - площа під кривою розвитку лісистості; $F_{2}$ - площа прямокутника 3 основою, що дорівнює площі водозбору до створу за $100 \%$ лісистості (рис. 1).
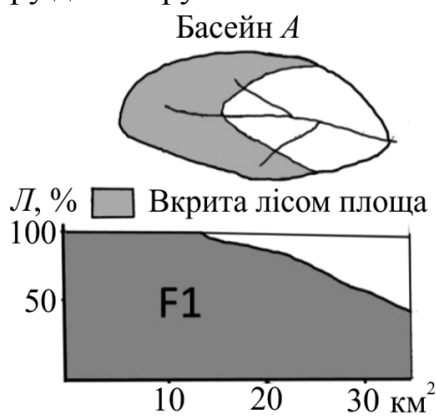

Площа басейну до створу
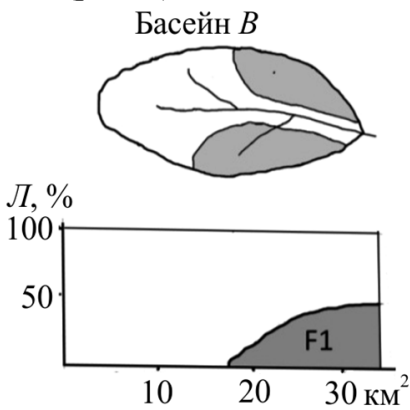

Площа басейну до створу Рис. 1. Розрахунок $\varepsilon$ для двох басейнів з однаковою лісистістю і різним розташуванням лісів (Pociask-Karteczka, 2003)

Величина $\varepsilon$ може змінюватися від 0 до 1 ; чим більше його значення, тим корисніше розташування лісів у басейні з погляду їх впливу на формування водопіль і паводків. 3 рис. 1 видно, що в разі суцільного розташування лісів лише у верхів'ї водозбору чи лише у нижній течії біля створу, показник $\varepsilon$ буде значно більший у басейні А навіть за однакової лісистості обох басейнів у замикаючому створі (Oliinyk, 2013; Pociask-Karteczki, 2003).

\section{Інформація про авторів:}

Кульчицький-Жигайло Ігор Євгенович, канд. с.-г. наук, старший науковий співробітник, доцент, кафедра екології. Email: ikylchytski@ukr.net

Цитування за ДСТУ: Кульчицький-Жигайло І. Є. Характер розташування лісів на водозборі гірської річки в Карпатах як один з чинників формування витрат води весняного водопілля. Науковий вісник НлтУ України. 2018, т. 28, № 5. С. 69-73.

Citation APA: Kulchytskyi-Zhyhaylo, I. Ye. (2018). The character of location of forests within the Carpathian mountains catchment as a factor of spring flood formation. Scientific Bulletin of UNFU, 28(5), 69-73. https://doi.org/10.15421/40280515 
Проаналізуємо інформативність цього показника за інших варіантів розташування лісів, як це зазвичай буває насправді. Нехай басейн був розбитий вверх по те- чії від створу на 10 однакових часткових ділянок пло-

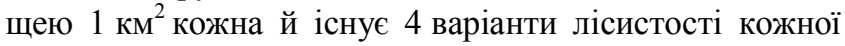
ділянки (табл. 1).

Табл. 1. Варіанти розташування лісів на водозборі

\begin{tabular}{|c|c|c|c|c|c|c|c|c|}
\hline \multirow[b]{2}{*}{$\begin{array}{l}\text { № ді- } \\
\text { лянки }\end{array}$} & \multicolumn{2}{|c|}{ Варіант 1} & \multicolumn{2}{|c|}{ Варіант 2} & \multicolumn{2}{|c|}{ Варіант 3} & \multicolumn{2}{|c|}{ Варіант 4} \\
\hline & $\begin{array}{c}\text { Площа лісів } \\
\text { на ділянці, } \\
\text { км}^{2}\end{array}$ & $\begin{array}{c}\text { Лісистість } \\
\text { до даного } \\
\text { створу Л, \% }\end{array}$ & $\begin{array}{c}\text { Площа лісів } \\
\text { на ділянці, } \\
\text { км² }^{2}\end{array}$ & $\begin{array}{c}\text { Лісистість } \\
\text { до даного } \\
\text { створу Л, \% }\end{array}$ & $\begin{array}{c}\text { Площа лісів } \\
\text { на ділянці, } \\
\text { км }^{2}\end{array}$ & $\begin{array}{c}\text { Лісистість } \\
\text { до даного } \\
\text { створу Л, \% }\end{array}$ & $\begin{array}{c}\text { Площа лісів } \\
\text { на ділянці, } \\
\text { км }^{2}\end{array}$ & $\begin{array}{c}\text { Лісистість } \\
\text { до даного } \\
\text { створу Л, \% }\end{array}$ \\
\hline 1 & 0,80 & 80,0 & 0,50 & 50,0 & 0 & 0,0 & 1 & 100,0 \\
\hline 2 & 0,70 & 75,0 & 0,70 & 60,0 & 0,13 & 6,5 & 1 & 100,0 \\
\hline 3 & 0 & 50,0 & 0,20 & 46,7 & 1,0 & 37,7 & 0,36 & 78,7 \\
\hline 4 & 0 & 37,5 & 0,90 & 57,5 & 1,0 & 53,3 & 0 & 59,0 \\
\hline 5 & 0,90 & 48,0 & 0,90 & 64,0 & 1,0 & 62,6 & 0 & 47,2 \\
\hline 6 & 0,50 & 48,3 & 0,30 & 58,3 & 1,0 & 68,8 & 0 & 39,3 \\
\hline 7 & 0,80 & 52,9 & 0,40 & 55,7 & 1,0 & 73,3 & 0 & 33,7 \\
\hline 8 & 0,50 & 52,5 & 0,29 & 52,4 & 1,0 & 76,6 & 0 & 29,5 \\
\hline 9 & 0,20 & 48,9 & 0,19 & 48,7 & 1,0 & 79,2 & 0 & 26,2 \\
\hline 10 & 0,10 & 45,0 & 0,10 & 45,0 & 1,0 & 81,3 & 0 & 23,6 \\
\hline
\end{tabular}

У варіантах 1 і 2 лісистість басейну однакова (45 \%), однаковий і показник $\varepsilon=0,538$. Однак розташування лісів відрізняється істотно (рис. 2).

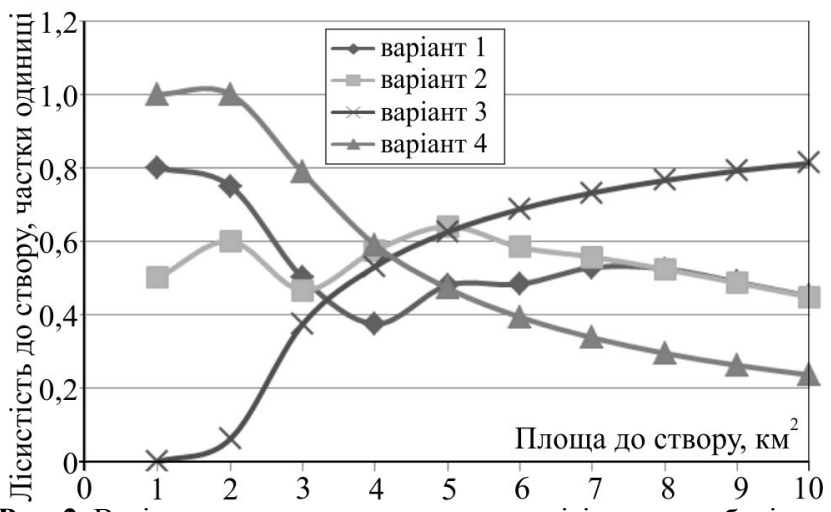

Рис. 2. Варіанти характеру розташування лісів на водозборі за однакового $\varepsilon=0,538$

За такого ж самого значення $\varepsilon$ лісистість водозборів може бути як $81,3 \%$, так і $23,6 \%$, тобто відрізнятися у 3,4 раза (варіанти 3 і 4). Окрім цього, для гідрологічних розрахунків $\varepsilon$ не враховує співвідношення часу водовіддачі та найбільшого часу добігання води до створу. Тому сам по собі $\varepsilon$, без урахування лісистості та інших факторів, не може характеризувати стокорегулювальну роль лісів на конкретному водозборі.

Оцінювання впливу розташування лісів на формування максимального стоку потрібно здійснювати на основі розрахунків гідрографів у багатоводні фази водного режиму. При цьому треба враховувати весь багатогранний механізм гідрологічної дії лісів.

Матеріал і методи дослідження. Розглянемо вплив розташування лісів на гідрограф весняного водопілля. Експериментально встановлено такі закономірності (Kozii, et al., 2017; Šípek \& Tesař, 2014; Varhola, Coops \& Weiler, 2010).

1. Ліси впливають на величину снігонакопичення і водозапаси в снігу на початок весняного сніготанення. Експериментально встановлено, що порівняно $з$ відкритою територією, під шпильковими лісами снігу накопичується менше. Щодо листяних лісів можливі такі варіанти: снігонакопичення тут дещо більше (через відсутність видування і меншу сублімацію під час заметілей) і снігонакопичення трохи менше завдяки перехопленню снігу кронами у безлистяному стані.

2. Ліси, особливо хвойні, сповільнюють інтенсивність сніготанення, зменшуючи радіаційне тепло та протидіючи поширенню адвективного. Відповідно зменшується мо- дуль стоку снігових вод. Схиловий стік з заліснених територій починається пізніше через більші початкові втрати води на інфільтрацію у менш промерзлий у лісах грунт.

3. Вплив лісу на тривалість сніготанення Тв залежить від його лісотаксаційних характеристик. Через менше снігонакопичення під стиглими шпильковими лісами Тв тут може скорочуватися, незважаючи на меншу інтенсивність сніготанення. 3-під середньовікових, середньоповнотних шпилькових лісів та листяних насаджень сніг сходить довше.

Моделювання впливу характеру розташування лісів на гідрограф весняного водопілля здійснено для водозбору річки Яблунька до створу в місті Турка (рис. 3). Річка розташована у Бескидах і $є$ лівим допливом річки

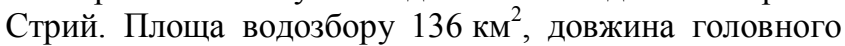
русла 21 км, ухил русла $11,3 \%$, середня висота 722 м НРМ, середній ухил $214 \%$, густота руслової мережі 1,53 км/км², лісистість 30,0 \%. Тривалість добігання води до створу з найвіддаленіших ділянок $\tau=6$ год.

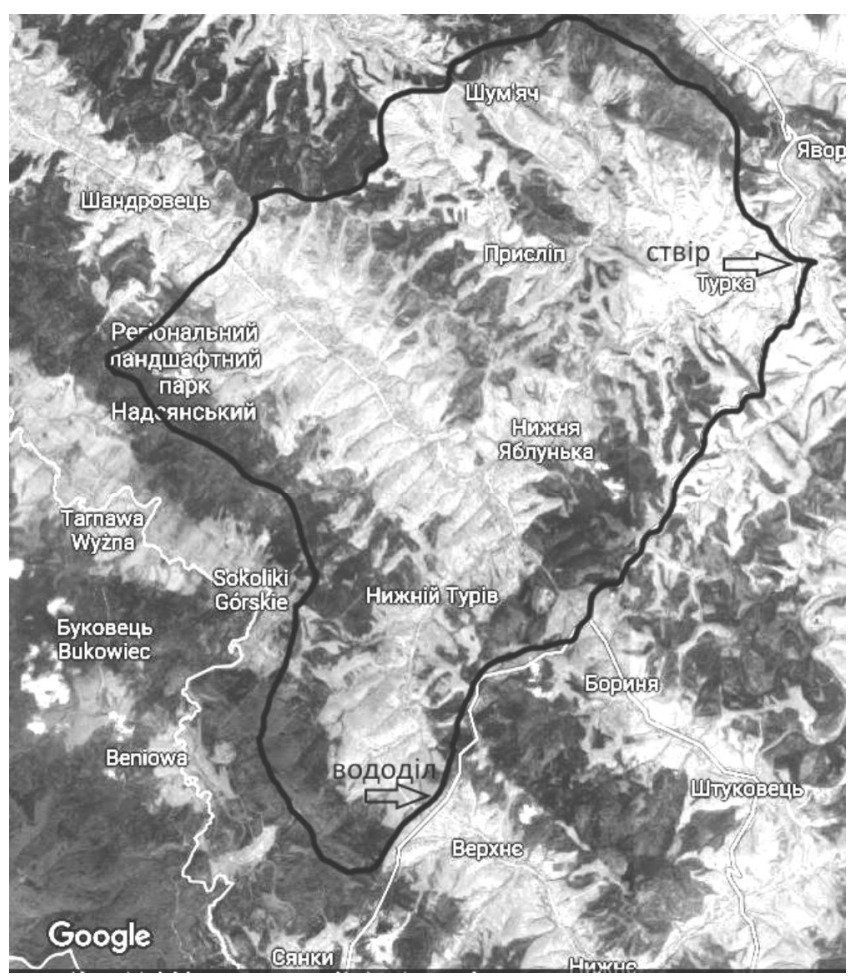

Рис. 3. Водозбір річки Яблунька до створу в місті Турка

Досліджено приуроченість до водозбору лісогосподарських одиниць різного підпорядкування до рівня 
кварталів і виділів і вивчено лісотаксаційні характеристики розташованих тут лісів. Вони належать до Львівського ОУЛМГ (Боринський ДЛГ: Яблунське лісницво - кв.17-19,21-24, Боринське лісництво - кв. 4-9; 11-14; 17-19; Турківський ДЛГ: Вовчанське лісництво - кв. 23, а також ОКС ЛГП "Галсільліс" (Турківський ДЛГП: Турківське лісництво - кв. 3,12, Верхньояблунська сільська рада - кв. 4-8,13,14,20, Нижньояблунська сільська рада - кв. 15,16,21-23, Нижньотурківська сільська рада, Лімнянське ліс-во - кв. 32-38, Присліпська сільська рада - кв. 39-41, Шум'ячська сільська рада - кв. 44-46, Турківська сільська рада). Ліси 3 переважанням хвойних порід становлять 95 \% площі, $69 \%$ займають насадження молодші за 60 років, схили крутизною 12-16 \% становлять $47 \%$.

Позаяк під час водопілля найцікавішими є максимальні витрати води, розрахунки здійснено лише для фази підйому гідрографа, допускаючи у цей період наявність суцільного снігового вкриття. Тоді модуль стоку з певної площі залежатиме від інтенсивності сніготанення і буде дорівнювати сумі водовіддачі з різних лісів та незаліснених площ. Інтенсивність сніготанення прийнята для типового температурного режиму в період весняного сніготанення (за матеріалами метеопоста в Турці) на основі опублікованих експериментальних досліджень (Kantor, 1981; Oliinyk, 2013) та власного аналізу матеріалів Закарпатської воднобалансової станції з урахуванням висоти водозбору та лісотаксаційних характеристик насаджень. Використано метод ізохрон, за якого на водозборі виділяють $m$ ділянок однакового часу добігання води до створу: $m=\tau / \tau_{0}$, де $\tau_{0}-$ прийнятий розрахунковий інтервал часу.

Зміна інтенсивності сніготанення і, відповідно, модуля стоку зі заліснених чи безлісних площ представлені дискретно для інтервалів часу $\tau_{0}$.

Під час сніготанення тривалість водовіддачі Тв значно більша від часу добігання $\tau$. Розглядаючи фазу підйому гідрографа, матимемо лише два періоди:

- період формування витрат з частини водозбору становить $i=1,2, \ldots m-1$ :

$$
Q_{i}=\sum_{j=1}^{i} q_{j} f_{i-j+1}, i=\overline{1, m-1}
$$

- період формування витрат з усієї площі водозбору $i \geq m$ :

$$
Q_{i}=\sum_{j=1}^{m} q_{i-j+1} f_{j}, i=\overline{1, m-1},
$$

де $f_{j}$ - площі ділянок між ізохронами, $q_{t}$ - модуль стоку y часі $t$.

Позначимо: $k_{1}^{\lambda x}, k_{2}^{\pi x}, \ldots k_{m}^{n x}-$ частка хвойних лісів, $k_{1}^{n л}, k_{2}^{л \pi}, \ldots k_{m}^{л n}$ - частка листяних лісів, $k_{1}^{\sigma}, k_{2}^{\sigma}, \ldots k_{m}^{\sigma}-$ частка безлісних територій у площі ділянок $f_{1}, f_{2}, \ldots f_{m}$ відповідно. Тоді:

- $k_{1}^{\lambda x} f_{1}, k_{2}^{n x} f_{2}, \ldots k_{m}^{n x} f_{m}$ - площі, зайняті хвойними лісами на ділянках $f_{1}, f_{2}, \ldots f_{m}$,

- $k_{1}^{n l} f_{1}, k_{2}^{n l} f_{2}, . . k_{m}^{n l} f_{m}$ - площі, зайняті листяними лісами на ділянках $f_{1}, f_{2}, \ldots f_{m}$,

- $k_{1}^{\sigma} f_{1}, k_{2}^{\sigma} f_{2}, \ldots k_{m}^{\sigma} f_{m}$ - безлісні площі на ділянках $f_{1}, f_{2}, \ldots f_{m}$.

Представимо витрату у замикаючому створі $Q_{i}$ як суму витрат, сформованих окремо стоком зі заліснених i безлісних частин ділянок

$$
Q_{i}=Q_{i}^{n x}+Q_{i}^{n l}+Q_{i}^{\sigma},
$$

де $Q_{i}^{n x}, Q_{i}^{n s}$, - витрати, сформовані стоком 3 ділянок хвойного, листяного лісу і безлісних територій відповідно.

Для двох періодів підйому гідрографа обчислюємо витрати згідно з наведеними вище формулами, тобто:

$$
\begin{gathered}
i=1,2, \ldots m-1: Q_{i}^{n x}=\sum_{j=1}^{i} q_{j}^{n x} k_{i-j+1}^{n x} f_{i-j+1}, Q_{i}^{\sigma}=\sum_{j=1}^{i} q_{j}^{\sigma} k_{i-j+1}^{\sigma} f_{i-j+1}, \\
Q_{i}^{n l}=\sum_{j=1}^{i} q_{j}^{n l} k_{i-j+1}^{n l} f_{i-j+1} ; \\
i \geq m: Q_{i}^{n x}=\sum_{j=1}^{m} q_{i-j+1 i}^{n x} k_{j}^{n x} f_{j}, Q_{i}^{n l}=\sum_{j=1}^{m} q_{i-j+1 i}^{n \pi} k_{j}^{n l} f_{j}, \\
Q_{i}^{\sigma}=\sum_{j=1}^{m} q_{i-j+1 i}^{\sigma} k_{j}^{\sigma} f_{j},
\end{gathered}
$$

де $q_{t}^{n x}, q_{t}^{n l}, q_{t}^{\sigma}-$ модулі стоку відповідно 3 ділянок хвойного, листяного лісу і безлісних територій у часі $t$.

Результати. Для розрахунків прийняли інтервал часу $\tau_{\mathrm{o}}=1$ год. Для нашого водозбору $\tau=6$ год відповідно

\begin{tabular}{|c|c|c|c|c|c|c|c|}
\hline \multirow{3}{*}{$\begin{array}{l}\text { Ділянка однакового } \\
\text { часу добігання води }\end{array}$} & \multirow{3}{*}{$\begin{array}{c}\text { Площа } \\
\text { ділянок, км² }\end{array}$} & \multicolumn{6}{|c|}{ Варіант } \\
\hline & & \multicolumn{2}{|c|}{1} & \multicolumn{2}{|c|}{2} & \multicolumn{2}{|c|}{3} \\
\hline & & $\begin{array}{c}\text { Безлісна } \\
\text { площа, км }\end{array}$ & $\begin{array}{c}\text { Заліснена } \\
\text { площа, км }\end{array}$ & $\begin{array}{c}\text { Безлісна } \\
\text { площа, км }\end{array}$ & $\begin{array}{l}\text { Заліснена } \\
\text { площа, км }\end{array}$ & $\begin{array}{c}\text { Безлісна } \\
\text { площа, км }\end{array}$ & $\begin{array}{c}\text { Заліснена } \\
\text { площа, км }\end{array}$ \\
\hline$f_{1}$ & 23 & 19,55 & 3,45 & 0 & 23 & 23 & 0 \\
\hline$f_{2}$ & 19 & 15,01 & 3,99 & 0,57 & 18,43 & 19 & 0 \\
\hline$f_{3}$ & 30 & 19,8 & 10,2 & 30 & 0 & 30 & 0 \\
\hline$f_{4}$ & 25 & 21,75 & 3,25 & 25 & 0 & 22,6 & 2,4 \\
\hline$f_{5}$ & 23 & 11,27 & 11,73 & 23 & 0 & 0 & 23 \\
\hline$f_{6}$ & 16 & 7,2 & 8,8 & 16 & 0 & 0 & 16 \\
\hline Всього & 136 & 94,6 & 41,4 & 94,57 & 41,43 & 94,6 & 41,4 \\
\hline
\end{tabular}
виділили 6 ділянок $f(m=6)$.

Розглянули 3 варіанти розташування лісів: 1 - фактичний, що ми визначили; 2 - умовний, за розташування наявної площі лісів біля створу; 3 - умовний, за розташування наявної площі лісів біля витоку (табл. 2).

Табл. 2. Варіанти розташування лісів на водозборі річки Яблунька

Вважали, що під хвойним лісом сніготанення починається на 12 год пізніше. Впродовж 185 год підйому гідрографа водопілля були періоди більш-менш синхронної зміни інтенсивності сніготанення і, відповідно, модуля стоку з безлісних і заліснених площ та асинхронної зміни цих показників.

Результати моделювання (рис. 4) показали, що на 16-ту год спостерігається максимальна різниця витрат води між наявним розташуванням лісів та варіантами 2 (10\%) і 3 (4\%), зумовлена відтермінуванням початку сніготанення в лісі.

Інші випадки різниці (3-7 \%) спричинені асинхронністю зміни модуля стоку в лісі та невкритій лісом площі - 51, 52 год та 80, 81 год. За однакового градієнта приросту чи зменшення модуля стоку на залісненій та безлісній території різниця між витратами води для різ- 
них варіантів розташування лісів не перевищувала 1 $3 \%$, причиною цієї різниці було різне співвідношення на розрахункову годину добутків відповідних модулів стоку на площу $f$.

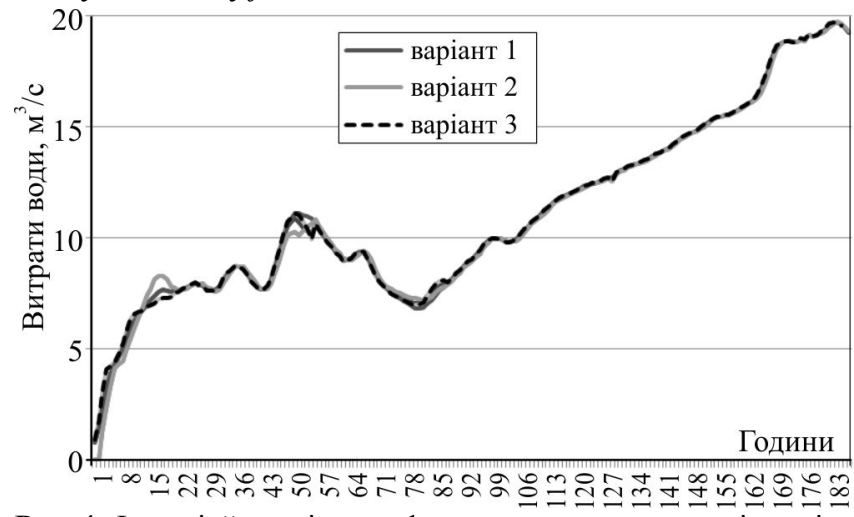

Рис. 4. Фаза підйому гідрографа стоку весняного водопілля річки Яблунька за різного розташування лісів на ньому

Висновки. Для оцінювання впливу характеру розташування лісів на формування стоку води весняних водопіль можна використовувати моделювання гідрографа методом ізохрон. Інтенсивності сніготанення потрібно визначати залежно від характеристик лісів та температурного режиму, модулі стоку на певний час - як їх суму із заліснених та безлісних площ. Для водозборів малих гірських річок Карпат, де тривалість весняної водовіддачі в десятки разів перевищує тривалість добігання води до створу, максимальні витрати будуть формуватися 3 усієї площі водозбору. За реальних інтенсивностей сніготанення відмінності в характері розташування лісів спричиняють різницю витрат води на початку підйому водності та за асинхронної зміні водовіддачі зі снігу з заліснених і безлісних територій, проте ця різниця не перевищує $10 \%$. У разі синхронної зміни водовіддачі різниця витрат становить $1-3 \%$. Вплив характеру розта- шування лісів може бути відчутнішим на великих водозборах та під час формування дощових паводків.

\section{Перелік використаних джерел}

Broxton, P. D., Harpold, A. A, Biederman, J. A., et al. (2015). Quantifying the effects of vegetation structure on snow accumulation and ablation in mixed-conifer forests. Ecohydrol, 8, 1073-1094. https://doi.org/10.1002/eco.1565

Dubakh, A. D. (1951). Les kak hydrolohycheskyi faktor. [Forest as hydrological factor]. Moscow-Leningrad: Hoslesbumizdat. [In Russian].

Kantor, P. (1981). Hydric effect of Norway spruce and beech in winter period. Prace VULHM, 58, 153-176.

Kozii, N., Laudon, H., Löfvenius, M. O., \& Hasselquist, N. J. (2017). Increasing water losses from snow captured in the canopy of boreal forests: A case study using a 30 year data set. Hydrological Processes, 1-10. https://doi.org/10.1002/hyp.11277

Mahat, V., \& Tarboton, D. G. (2014). Representation of canopy snow interception, unloading and melt in a parsimonious snowmelt model. Hydrol. Process, 28, 6320-6336. https://doi.org/10.1002/hyp.10116

Oliinyk, V. S. (2013). Hidrolohichna rol lisiv Ukrainskykh Karpat. [Hydrological role of the forests of Ukrainian Carpathians]. IvanoFrankivsk: NAIR. [In Ukrainian].

Pociask-Karteczki, J. (Ed.). (2003). Zlewnia wlasciwosci i procesy. [Watershed properties and processes]. Krakow: IGIGP. [In Polish].

Podkur, P. P. (1981). Metodyka opredelenyia ratsyonalnoho v hydrolohycheskom otnoshenyy razmeshchenyia lesnykh nasazhdenyi po ploshchady vodosborov. [Method of determination of the rational in a hydrological sense placing of the forest planting on the watershed area]. Forestry and Forest Melioration, 59, 31-36. [In Russian].

Šípek, V., \& Tesař, M. (2014). Seasonal snow accumulation in the mid-latitude forested catchment. Biologia 69/11, 1562-1569. https://doi.org/10.2478/s11756-014-0468-3

Varhola, A., Coops, N. C., \& Weiler, M. (2010). Dan Moore Forest canopy effects on snow accumulation and ablation: An integrative review of empirical results. Journal of Hydrology, 392, 219-233. https://doi.org/10.1016/j.jhydrol.2010.08.009

И. Е. Кульчицкий-Жигайло
Национальный лесотехнический университет Украинь, г. Львов, Украина

\section{ХАРАКТЕР РАЗМЕЩЕНИЯ ЛЕСОВ НА ВОДОСБОРЕ ГОРНОЙ РЕКИ В КАРПАТАХ КАК ОДИН ИЗ ФАКТОРОВ ФОРМИРОВАНИЯ РАСХОДОВ ВОДЫ ВЕСЕННЕГО ПОЛОВОДЬЯ}

Дана оценка возможности применения показателя развития лесистости водосбора $\varepsilon$ для характеристики размещения лесов на нем. Установлена малая информативность $\varepsilon$ для лесогидрологических исследований. Проанализированы опубликованные экспериментальные исследования и материалы Закарпатской воднобалансовой станции о влиянии хвойных и лиственных лесов на величину снегонакопления и интенсивность снеготаяния в Карпатах. Изучены морфометрические характеристики исследуемого водосбора реки Яблунька до г. Турка в Бескидах, размещение лесов на нем, их породный и возрастной состав. Площади водосбора 136 км$^{2}$, средняя высота н. у. м. 722 м. Максимальное время добегания воды до створа $\tau=6$ часов. Лесистость водосбора 30, 95 \% площади занимают древостои с преобладанием ели европейской и пихты белой. При разном размещении лесов на этом водосборе смоделирован почасовой расход воды на подъеме гидрографа для типичного температурного режима в период весеннего снеготаяния. Установлено, что для малых водосборов, где $\tau$ в десятки раз меньше времени снеготаяния, характер размещения лесов не играет значительной роли в формировании среднечасовых расходов воды. Разница между расходами воды весеннего половодья для различных вариантов размещения лесов, обусловленная задержанием начала снеготаяния в хвойных лесах, не превышает $10 \%$.

При синхронном изменении интенсивности снеготаяния в лесу и на открытых участках разница между расходами воды для разного размещения лесов равна 1-3\%, при асинхронном изменении $-3-7 \%$.

Ключевые слова: гидрологическое влияние хвойных лесов; показатель развития лесистости; снеговые воды; моделирование гидрографа.

I. Ye. Kulchytskyi-Zhyhaylo

Ukrainian National Forestry University, Lviv, Ukraine

\section{THE CHARACTER OF LOCATION OF FORESTS WITHIN THE CARPATHIAN MOUNTAINS CATCHMENT AS A FACTOR OF SPRING FLOOD FORMATION}

Assessment of the possibility to use forest cover development parameters as a characteristic of forests location within a catchment showed its relatively low informative value for the forest hydrological research. Published empirical data together with materials of the Transcarpathian water-balance station were analysed to determine how deciduous and coniferous trees influence 
snow accumulation and snowmelt intensity in the Carpathian Mountains. The morphometric parameters, forests location, their structure and age have been investigated for the Yablunka study catchment (outlet in Turka town, in the Beskyds). The catchment area is $136 \mathrm{~km}^{2}$, mean elevation above the sea level is $772 \mathrm{~m}$, the length of the main channel is $21 \mathrm{~km}$, and a maximum transit time is 6 hours. Forests cover $30 \%$ of the catchment area and $95 \%$ of them are coniferous stands of Norway spruce (Picea abies) and European silver fir (Abies alba). Stands younger than 60 year old dominate and represent $69 \%$ of total forests within the catchment. An hourly water discharge during the rise of hydrograph pick was modelled under the typical for spring flood temperature regime and under different scenarios of forests locations within the catchment. The model takes into account a delay in beginning of snowmelt in the forest and the difference in snowmelt rates between the open areas and areas under coniferous stands. Changes in snowmelt rate are caused by combination of the short and long wave radiation and can occur synchronously at the open and forested areas, or asynchronously. For the small catchment, where the maximum transit time is substantially lower a snowmelt rate, forest location of forests does not substantially influence hourly discharge values and almost all runoff initiates from the entire area. The difference in discharges during spring floods under different scenarios of forest locations caused by the delay in snowmelt in coniferous stands does not exceed $10 \%$. When the snowmelt intensity in the forest and open areas are synchronous, then the difference between discharges under the different forest location scenarios is 1-3\% and it increases to 3-7 \% in case of asynchrony.

Keywords: hydrological impact of coniferous forests; index of forest cover development; snow water; hydrograph simulations. 